\title{
Isolamento e caracterização de estirpes de Bacillus thuringiensis coletadas em solos do oeste baiano
}

\author{
Lílian Botelho Praça' \\ Cristiane Morinaga ${ }^{2}$ \\ Patrícia Teles Medeiros ${ }^{3}$ \\ Viviane Montaigner Melatti ${ }^{4}$ \\ Erica Soares Martins ${ }^{5}$ \\ Vinicius Fiuza Dumas 6 \\ Roseane Falcão ${ }^{7}$ \\ Rose Gomes Monnerat ${ }^{8}$
}

\section{Resumo}

A partir de 21 amostras de solos da região oeste da Bahia, foram isoladas nove estirpes de B. thuringiensis. As estirpes de B. thuringiensis foram testadas contra lagartas de Spodoptera frugiperda, Anticarsia gemmatalis, Plutella xylostella e Anthonomus grandis. Das nove estirpes, duas apresentaram efetividade, a S2183 contra S. frugiperda e a S2186 contra S. frugiperda, A. gemmatalis e P. xylostella. Com relação ao $A$. grandis, nenhuma das estirpes apresentou mortalidade acima de 70\%. Essas estirpes foram submetidas à bioensaios para cálculo da CL50 e a caracterizações bioquímicas e moleculares. Em bioensaio, a S2183 não apresentou efetividade nas doses recomendadas contra os insetos testados e S2186 apresentou

\footnotetext{
${ }^{1}$ MSc. Agronomia. Embrapa Recursos Genéticos e Biotecnologia; e-mail: lilian@cenargen. embrapa.br

2 BSc. Engenharia Agronômica; e-mail: cris_morinaga@yahoo.com.br

MSc. Agricultura Tropical; e-mail: patteles@ig.com.br

${ }^{4}$ MSc. Ciências Agrárias; e-mail: vivimelatti@gmail.com

${ }^{5}$ PhD Biologia Molecular; e-mail: erica@ cenargen.embrapa.br

${ }^{6}$ MSc. Biologia Molecular; e-mail: vfdumas@yahoo.com.br

7 MSc. Ciências Genômicas e Biotecnologia; Embrapa Recursos Genéticos e Biotecnologia; e-mail: falcao@cenargen.embrapa.br

${ }^{8}$ PhD Ciências Agrárias; Embrapa Recursos Genéticos e Biotecnologia; e-mail: rose@cenargen.embrapa.br
} 
uma CL50 de $375 \mu \mathrm{g} / \mathrm{mL}$ apenas para $P$. xylostella. As estirpes apresentaram duas proteínas principais de 100 e $70 \mathrm{kDa}$. Somente S2186 apresentou produtos de PCR para o gene cry 2 e cristais bipiramidais, apresentando-se semelhante ao padrão $B$. thuringiensis subespécie kurstaki.

Palavras-chave: Spodoptera frugiperda. Inseticidas. Controle biológico. Insetos.

\section{Introdução}

O Brasil é um país que possui vocação agrícola natural. Apresenta um clima diversificado, chuvas regulares, energia solar abundante e quase $13 \%$ de toda a água doce disponível no planeta. Possui uma área agricultável de 388 milhões de hectares, dos quais 90 milhões ainda não foram explorados. O agronegócio representa 33\% do Produto Interno Bruto (PIB) brasileiro, 42\% das exportações totais e 37\% dos empregos gerados no país (MINISTÉRIO DA AGRICULTURA PECUÁRIA E ABASTECIMENTO, 2006).

A produção agropecuária brasileira é uma das maiores do mundo. Isso se deve não somente às características edafoclimáticas do país, mas também à utilização de tecnologias avançadas e à modernização da atividade rural. Porém, mesmo com a alta tecnificação da agricultura, grandes são as perdas devidas ao ataque de pragas, o que leva ao uso indiscriminado de inseticidas químicos, causando diversos problemas para o homem e para o meio ambiente, levando ainda ao aparecimento de populações de insetos resistentes. Com isso, o controle biológico surge como uma alternativa importante para o controle de insetos.

Existem alguns insetos que atacam culturas de grande importância no Brasil, que muitas vezes podem inviabilizar o cultivo por serem pragas chaves na agricultura. São eles: Anthonomus grandis (Coleoptera: Curculionidade), em algodão, Anticarsia gemmatalis (Lepidoptera: Noctuidae), na soja, Plutella xylostella (Lepidoptera: Plutellidae), em brássicas e Spodoptera frugiperda (Lepidoptera: Noctuidae), atacando principalmente o milho.

O bicudo do algodoeiro, A. grandis, chegou ao Brasil em 1983 (GALLO et al., 2002) e seu ataque chegou a inviabilizar o cultivo do algodão em diversas regiões do país, em especial, na região nordeste. A época de maior ataque do bicudo 
ocorre entre os $50^{\circ}$ e o $90^{\circ}$ dias após a emergência. O custo de produção do algodão é muito alto, devido à intensa utilização de produtos químicos no controle dessa praga (GONDIM et al., 2001).

Outra praga de grande importância no Brasil é A. gemmatalis, principal praga da cultura da soja, conhecida popularmente como lagarta da soja. Essa praga ataca a cultura durante a fase vegetativa e, em alguns casos, na floração, chegando a ocasionar 100\% de destruição foliar (GAZZONI; YORINIORI, 1995).

Pode-se ainda mencionar a traça-das-cruçíferas, $P$. xylostella, principal praga que ataca as brássicas e causa sérios danos nos plantios de couve, couve-flor e repolho. Essa praga se alimenta das folhas, reduzindo sua área e impedindo um bom desenvolvimento dessas plantas (CASTELO BRANCO, 1999).

No Brasil, S. frugiperda, conhecida como lagarta do cartucho do milho, ataca não somente o milho, mas também diversas outras culturas, ocasionando reduções de produtividade superiores a 30\% (CRUZ; FIGUEIREDO; MATOSO, 1999).

Dentre os agentes de controle biológico de ocorrência natural com possibilidade de utilização no controle dos insetos acima citados, as espécies do gênero Bacillus merecem especial destaque. Algumas espécies se caracterizam pela produção de toxinas e enzimas, causando doenças nos insetos infectados. A espécie mais estudada e utilizada como princípio ativo de bioinseticidas é Bacillus thuringiensis, sendo o mais produzido e vendido em todo o mundo para o controle de lagartas desfolhadoras (PRAÇA, 2003).

O objetivo deste trabalho foi isolar e selecionar novas estirpes de $B$. thuringiensis provenientes de solo da região oeste da Bahia e testá-las contra A. grandis, A. gemmatalis, P. xylostella, e S. frugiperda e, em seguida, caracterizá-las por meio de métodos moleculares, bioquímicos e ultraestruturais.

\section{Material e métodos}

\subsection{Coleta das amostras de solo e isolamento das estirpes}

As amostras de solo foram coletadas em duas fazendas de produção de grãos na região de Correntina - Bahia, com o auxílio de uma espátula e armazenadas 
em tubos tipo eppendorf esterilizados. Todos os solos estavam secos, e retirouse apenas uma pequena quantidade da camada mais superficial do solo. As áreas foram escolhidas ao acaso. $\mathrm{O}$ isolamento das estirpes foi realizado segundo o método da Organização Mundial da Saúde (ORGANIZAÇÃO MUNDIAL DA SAÚDE, 1987).

Primeiramente, colocou-se $1 \mathrm{~g}$ do solo em um eppendorf e adicionou-se $1 \mathrm{ml}$ solução salina estéril. As soluções foram homogeneizadas e submetidas a choque térmico ( $80{ }^{\circ} \mathrm{C}$ por 12 minutos / gelo por 5 minutos). Em seguida foram plaqueadas em meio NYSM (caldo nutriente, extrato de levedura, $\mathrm{MnCl}_{2}, \mathrm{MgCl}_{2}$, $\mathrm{CaCl}_{2}$ ) com antibiótico (YOUSTEN, 1984), com modificações na composição dos sais e incubadas por 24 horas. O meio foi acrescido de penicilina numa concentração de $100 \mathrm{mg} / \mathrm{L}$.

Após 24 horas, as colônias crescidas em penicilina com tamanho médio de aproximadamente de $0,5 \mathrm{~cm}$, cores esbranquiçadas, opacas e bordas irregulares, foram identificadas como típicas de B. thuringiensis ou B. cereus. Depois de identificadas e selecionadas, foram inoculadas em meio líquido NYSM por 48 a 72 horas em incubador rotativo, a $28^{\circ} \mathrm{C}$ e $200 \mathrm{rpm}$.

Após completa esporulação, as estirpes foram visualizadas em microscópio de contraste de fases para observação da presença de células vegetativas, esporos e cristais. Esse procedimento foi feito, principalmente, para caracterizar e confirmar se as estirpes eram de B. thuringiensis.

\subsection{Bioensaios}

Inicialmente foram feitos bioensaios seletivos. As estirpes foram crescidas em meio NYSM por 48 a 72 horas, a $200 \mathrm{rpm}$ e $28^{\circ} \mathrm{C}$ até a completa esporulação. Antes de cada bioensaio, os caldos crescidos foram visualizados em microscópio de contraste de fases, para confirmar a presença de esporos e cristais. Depois, as estirpes foram testadas; as que apresentaram mortalidade igual ou superior a $75 \%$ foram selecionadas e submetidas à bioensaios de diluições com a cultura bacteriana liofilizada (PRAÇA, 2003). Os dados de mortalidade obtidos em bioensaios de dose foram analisados através de Probits (FINNEY, 1971), a concentração letal necessária para matar $50 \%$ da população testada (CL50) foi determinada. 
Para liofilização da cultura bacteriana, primeiramente foi feito pré-inoculo; para isso as estirpes foram crescidas em meio NYSM por 16 horas. Após as 16 horas, esse pré-inóculo foi passado para um recipiente maior e crescido por 72 horas em incubador rotativo nas mesmas condições do pré-inóculo. Em seguida, foi feita microscopia óptica das estirpes para confirmar a presença de esporos e cristais. A cultura bacteriana foi transferida para tubos falcon devidamente identificados. Após a pesagem, os tubos foram colocados na centrífuga por 30 minutos a 10.000 rpm e $4^{\circ} \mathrm{C}$.

O sobrenadante de cada frasco foi descartado e ressuspendeu-se o "pellet" em $10 \%$ de água destilada autoclavada. As células ressuspensas foram transferidas para uma ampola de vidro identificado com o número da estirpe e data, vedado com papel alumínio e zap, e congelado "over night". No dia seguinte, os frascos foram levados para o Liofilizador (Labconco) por 18 horas. Depois de liofilizado, o material foi armazenado em freezer.

\subsubsection{Contra A. grandis}

Os bioensaios seletivos foram realizados, incorporando-se $10 \mathrm{ml}$ da cultura bacteriana em $35 \mathrm{~mL}$ de dieta artificial, vertida em placas de Petri (90x15 mm). Após solidificação da dieta, foram feitos 15 furos de aproximadamente $0,6 \mathrm{~mm}^{2}$, onde se colocaram larvas neonatas (uma por furo). Utilizaram-se quatro repetições e uma placa sem a bactéria que serviu como testemunha. Ao término, as placas foram acondicionadas em BOD à $27^{\circ} \mathrm{C}$ e fotoperíodo de 14 horas. No sétimo dia, realizou-se a única leitura. Bacillus thuringiensis subespécie tenebrionis (Btt) foi utilizado como padrão e controle positivo.

\subsubsection{Contra S. frugiperda}

Os bioensaios foram realizados espalhando-se $35 \mu \mathrm{L}$ da cultura bacteriana na dieta distribuída previamente em placas de cultivo de células com 24 poços. Após a absorção da cultura bacteriana pela dieta, uma larva de segundo estágio foi colocada em cada poço. Uma placa foi deixada sem a bactéria, como testemunha. As placas foram devidamente fechadas com tampas de acrílico e ligas 
elásticas e colocadas na sala de bioensaio, regulada sob temperatura de $27 \pm 2$ ${ }^{\circ} \mathrm{C}$. A primeira leitura foi feita 48 horas após o início do ensaio, ocasião em que as lagartas foram transferidas para copinhos de plástico de $50 \mathrm{ml}$, contendo dieta livre do bacilo. No sétimo dia, foi feita a segunda e última leitura. (MONNERAT; SILVA; SILVA-WERNECK, 2001; SILVA-WERNECK; MONNERAT, 2001). Bacillus thuringiensis subsp. kurstaki (Btk) foi utilizado como padrão e controle positivo.

Para o bioensaio de dose, as lagartas utilizadas tiveram a mesma procedência das lagartas do bioensaio seletivo. Porém, para esse bioensaio, utilizou-se bactéria liofilizada e várias diluições a partir do material liofilizado.

Pesou-se $1 \mathrm{mg}$ da bactéria liofilizada em tubo eppendorf e adicionouse $1 \mathrm{~mL}$ de água destilada estéril. Homogeneizou-se bem o material com a ajuda de um agitador tipo "vortex", e obteve-se a suspensão I. A partir dessa suspensão, obteve-se a suspensão II, pegando-se $571,4 \mu \mathrm{L}$ da suspensão I e adicionando-se 428,6 $\mu \mathrm{L}$ de água, obtendo-se uma concentração final de 571,4 $\mu \mathrm{g} / \mathrm{mL}$. Em seguida, preparou-se $1 \mathrm{ml}$ de cada uma das diluições conforme descrito em Praça (2003).

Depois de feitas todas as diluições, prosseguiu-se o bioensaio da mesma forma que para o bioensaio seletivo, utilizando-se uma placa para cada diluição.

\subsubsection{Contra A. gemmatalis}

Os bioensaios foram realizados, espalhando-se $150 \mu \mathrm{l}$ da cultura bacteriana na dieta distribuída previamente em copos descartáveis de $50 \mathrm{ml}$. Após a absorção da cultura bacteriana pela dieta, dez larvas de segundo estágio de A. gemmatalis foram colocadas em cada copinho que, em seguida, foram fechados com tampas de acrílico e incubados nas mesmas condições de S. frugiperda. Duas repetições foram feitas e um copo foi deixado sem a bactéria, como testemunha. A primeira leitura foi feita 48 horas após o início do ensaio, ocasião em que as lagartas foram transferidas para novos copos, contendo dieta livre do bacilo. No quinto dia, foi feita a segunda e última leitura (MONNERAT; SILVA; SILVA-WERNECK, 2001; SILVAWERNECK; MONNERAT, 2001). Bacillus thuringiensis subsp. kurstaki (Btk) foi utilizado como padrão e controle positivo. 
Para o bioensaio de dose, o procedimento utilizado foi igual ao descrito para S. frugiperda, com exceção da última leitura, que foi feita no quinto dia e não no sétimo, como o de Spodoptera.

\subsubsection{Contra P.xylostella}

Os bioensaios foram realizados, lavando-se folhas de couve, passando-se levemente a esponja sobre elas para tirar a cera superficial. Em seguida, foram deixadas de molho em solução de hipoclorito a $5 \%$ por 20 minutos e imersas em água destilada e secas com papel toalha. Em seguida, essas folhas foram imersas por 10 minutos em uma solução com $10 \mathrm{ml}$ da cultura bacteriana diluída em $90 \mathrm{ml}$ de água destilada e $30 \mu \mathrm{L}$ do espalhante adesivo Extravon. Após esse processo, as folhas foram colocadas para secar em caixas de papelão penduradas em um varal de barbante por cerca de uma hora a temperatura ambiente (em torno de $28^{\circ} \mathrm{C}$ ). Após a secagem, cada folha e 10 lagartas de terceiro instar foram colocadas dentro de uma placa de Petri descartável $(90$ x $15 \mathrm{~mm})$ forrada com papel filtro e previamente identificada com o nome da estirpe. As placas foram fechadas com a tampa e lacradas com zap. Para cada estirpe, foram feitas duas repetições. A primeira leitura foi feita 48 horas após o início do ensaio, ocasião em que as lagartas foram transferidas para novas folhas livres do bacilo. No quinto dia, foi feita a segunda e última leitura.

Para o bioensaio de doses com P. xylostella, a lavagem das folhas foi feita da mesma forma do bioensaio seletivo, e as lagartas tiveram a mesma procedência, porém, utilizado material liofilizado.

Para cada estirpe foram feitas oito diluições e para cada diluição, três repetições com três folhas para cada uma das diluições. A primeira diluição foi chamada de Solução Mãe, a 10 \% (10-1). Foi pesada 0,1 grama da estirpe liofilizada e adicionados $10 \mathrm{ml}$ de solução salina. $O$ restante da diluição foi feito de forma seriada e se colocou $0,5 \mathrm{ml}$ da solução mãe em $4,5 \mathrm{ml}$ de solução salina. A sequência foi feita da mesma forma, colocando-se $0,5 \mathrm{ml}$ da solução anterior na próxima diluição e assim por diante.

Em cada copo previamente identificado com o número da estirpe e a respectiva diluição, colocou-se um $\mathrm{ml}$ da diluição em $99 \mathrm{ml}$ de água destilada e $30 \mu \mathrm{L}$ 
de espalhante adesivo. Três folhas foram imersas em cada um dos copos por cerca de dez minutos. Em seguida, as folhas foram colocadas no varal de papelão e barbante até a secagem completa. Todas as outras etapas do bioensaio foram feitas da mesma forma que para o bioensaio seletivo. Foram utilizadas três repetições para cada diluição e para cada uma das estirpes testadas.

\subsection{Eletroforese de proteínas em gel de poliacrilamida (SDS-PAGE $10 \%$ )}

\subsubsection{Preparação das misturas esporos-cristais}

As estirpes selecionadas foram inoculadas em meio NYSM por 72 horas em incubador rotativo a $28^{\circ} \mathrm{C}$ e $200 \mathrm{rpm}$ e, em seguida, as proteínas foram extraídas de acordo com Lecadet et al. (1991). As culturas bacterianas foram transferidas na quantidade de 1,5 ml para tubos Eppendorf de 1,5 ml, previamente autoclavados e centrifugados a $14000 \mathrm{rpm}$, em microcentrífuga Eppendorf, por 15 minutos. Esse passo foi repetido por três vezes. O sobrenadante foi descartado e o sedimento foi ressuspendido em $1,5 \mathrm{ml}$ de $\mathrm{NaCl} 0,5 \mathrm{M}$ e centrifugado a $14000 \mathrm{rpm}$ por 15 minutos. O sobrenadante foi descartado e as paredes do tubo eppendorf foram secas com papel filtro. Os sedimentos foram lavados por duas vezes com 1,5 ml de uma solução de inibidores de protease (PMSF a 1 mm, EDTA 100 mm e EGTA 40 $\mathrm{mm}$ ) e centrifugados a $14.000 \mathrm{rpm}$ por 15 minutos. Descartou-se o sobrenadante e os sedimentos foram ressuspendidos em $500 \mu \mathrm{L}$ de PMSF A $1 \mathrm{~mm}$. As amostras foram armazenadas a $-20^{\circ} \mathrm{C}$.

\subsubsection{Análise das proteínas em gel de Poliacrilamida-SDS (SDS-PAGE)}

As preparações de esporos-cristais das estirpes foram analisadas por eletroforese em gel de poliacrilamida-SDS a 10 \% (LAEMMLI, 1970). Alíquotas de $20 \mu \mathrm{l}$ das preparações de esporos-cristais foram diluídas em tampão de amostra de proteína $4 \mathrm{X}$ (1,5 M Tris- $\mathrm{HCl}, \mathrm{pH}$ 6,8, glicerol $10 \%$, SDS $2 \%$, $2 \beta$-mercaptoetanol $5 \%$, azul de bromofenol) fervidas a $100{ }^{\circ} \mathrm{C}$ por 5 minutos e aplicadas em gel de poliacrilamida $12 \%$. Foram usados $5 \mu \mathrm{L}$ de marcador de proteína de alto e baixo peso molecular (Broad Range- Promega). A eletroforese foi realizada em aparelho Hoefer miniVE vertical electroforesis system 
- Amersham Pharmacia, contendo tampão de corrida 1X (Tris-base, glicina, SDS), a uma voltagem constante de $120 \mathrm{~V}$, por cerca de duas horas. O gel foi corado em solução corante de Comassie Blue (40\% metanol, $10 \%$ de ácido acético e $25 \%$ de Comassie Blue 250-R) por quatorze horas e descorado em solução com $40 \%$ de metanol e $10 \%$ de ácido acético por duas horas até a visualização dos perfis proteicos das estirpes. Bacillus thuringiensis subsp. kurstaki foi utilizado como padrão.

\subsection{Caracterização molecular}

A extração do DNA total das estirpes selecionadas foi realizada segundo metodologia descrita por Bravo et al. (1998). Foram utilizados oligonucleotídeos gerais na identificação dos genes cry1 e cry2 (CERON et al., 1994, 1995; BRAVO et al., 1998).

Para a realização da PCR, $15 \mu \mathrm{L}$ do DNA extraído, foram transferidos para um tubo contendo $2 \mu \mathrm{L}$ de cada "primer " a $12,5 \mathrm{mM}, 1 \mu \mathrm{L}$ de dNTP mix a $10 \mu \mathrm{M}, 5 \mu \mathrm{L}$ de tampão 10x e $0,5 \mu \mathrm{L}$ de Taq DNA polimerase $(5,0 \mathrm{U} / \mu \mathrm{L}) \mathrm{em}$ um volume total de $50 \mu \mathrm{L}$. As amplificações foram processadas em termociclador MJ Research, Inc. (PTC-100TM). Uma alíquota de $24 \mu \mathrm{L}$ de cada produto de PCR foi analisada em gel de agarose $2 \%$, corado com brometo de etídio (1 $\mu \mathrm{g} / \mathrm{mL}$ ) por 20 minutos e descorado em água destilada por 15 minutos. As bandas foram visualizadas em transluminador sob luz UV e fotografadas em foto-documentador modelo Eagle Eye (Stratagene). A estirpe B. thuringiensis subsp. kurstaki (Btk) foi utilizada como padrão.

\subsection{Microscopia eletrônica das estirpes}

As estirpes de B. thuringensis, depois de liofilizadas, foram depositadas sobre suportes metálicos e cobertas com ouro por 180 segundos, utilizando-se metalizador Emitech Modelo K550 e observadas em microscópio eletrônico de varredura Zeiss modelo DSM 962 (PRAÇA, 2003). 


\section{Resultados e discussão}

\subsection{Coleta das amostras de solo, isolamento e caracterização morfológica dos isolados}

A coleta das amostras foi realizada em locais escolhidos ao acaso. Após o isolamento e plaqueamento das amostras de solo, observou-se o crescimento de 21 colônias de Bacilos. Dessas, nove cresceram em penicilina com cores esbranquiçadas, opacas e bordas irregulares, apresentando aspecto típico de B. thuringiensis ou B. cereus. As colônias foram identificadas e inoculadas em meio líquido NYSM.

Após 48 horas de crescimento ou completa esporulação, pôde-se confirmar que os isolados que cresceram em meio com penicilina correspondiam à espécie B. thuringiensis, por apresentar esporos alongados com formato elipsoidal e alguns cristais pequenos e, às vezes, bipiramidais. Nenhuma colônia foi identificada como típica de B. cereus, pois em todos os caldos crescidos foram visualizados cristais e B. cereus não possui cristais. Após a visualização dos esporos e cristais em microscópio de contraste de fase, nove estirpes foram identificadas como B. thuringiensis. Essas estirpes foram armazenadas no Banco de Bactérias de Invertebrados do Laboratório de Bactérias Entomopatogênicas da Embrapa Recursos Genéticos e Biotecnologia.

\subsection{Bioensaios}

Após identificação e armazenamento das estirpes de Bacilos, as da espécie B. thuringiensis foram selecionadas para a continuidade dos trabalhos. Foram testadas nove estirpes; duas delas, S2183 e S2186, causaram mortalidade nos insetos da Ordem Lepidoptera testados e nenhuma delas ocasionou mortalidade igual ou superior a $75 \%$ contra A. grandis. A estirpe S2183 gerou mortalidade de $75 \%$ apenas contra larvas de $S$. frugiperda, e a estirpe S2186 demonstrou atividade de $75 \%, 80 \%$ e $100 \%$ contra as larvas de S. frugiperda, A. gemmatalis e P. xylostella, respectivamente (Tabela 1 ).

Com relação ao bioensaio de dose, não foi possível calcular a CL50 da estirpe S2183 contra larvas de S. frugiperda, A. gemmatalis e P. xylostella e da estirpe S2186 contra S. frugiperda e A. gemmatalis. Em relação a P. xylostella, a estirpe 
S2186 apresentou baixa toxicidade com uma CL50 de $375 \mu \mathrm{g} / \mathrm{mL}$, podendo-se considerar essa estirpe pouco efetiva, comparando-se com os resultados apresentados pela estirpe padrão Btk HD-1 e com outros trabalhos publicados por Monnerat et al. (2007) e Santos et al. (2009) com outras estirpes de B. thuringiensis. Esse fato se deve, provavelmente, à presença de um único gene, o gene cry2, na estirpe S2186, já que esse gene, isoladamente, apresenta baixa atividade para insetos da ordem Lepidoptera.

Tabela 1 - Porcentagem de Mortalidade de estirpes de Bt em larvas de A. grandis, S. frugiperda, A. gemmatalis e P. xylostella após bioensaios seletivos.

\begin{tabular}{|c|c|c|c|c|}
\hline \multirow{2}{*}{ Estirpes } & \multicolumn{4}{|c|}{ Mortalidade (\%) } \\
\cline { 2 - 5 } & \multirow{2}{*}{ A. grandis } & S. frugiperda & \multirow{2}{*}{ A. gemmatalis } & \multirow{2}{*}{ P. xylostella } \\
\hline S2172 & 55 & 42 & 0 & 0 \\
\hline S2173 & 68 & 50 & 5 & 0 \\
\hline S2179 & 55 & 42 & 0 & 15 \\
\hline S2180 & 48 & 25 & 7 & 15 \\
\hline S2182 & 40 & 66 & 0 & 10 \\
\hline S2183 & 66 & 75 & 10 & 0 \\
\hline S2185 & 50 & 50 & 0 & 0 \\
\hline S2186 & 48 & 75 & 80 & 100 \\
\hline S2192 & 68 & 67 & 7 & 0 \\
\hline
\end{tabular}

\subsection{Eletroforese de proteínas em gel de poliacrilamida (SDS-PAGE 10\%)}

Por meio da análise da eletroforese da mistura de esporos e cristais das estirpes S2183 e S2186, verificou-se que as preparações apresentaram um padrão eletroforético com a presença de uma banda de $100 \mathrm{kDa}$ e outra de $70 \mathrm{kDa}$ (Figura 1), esta última assemelha-se a uma das bandas presentes no perfil do padrão contra lepidópteros (Btk) (HÖFTE et al., 1988; LERECLUS; DELÉCLUSE; LECADET, 1993). Esta segunda banda corresponde ao produto de expressão da proteína Cry2; porém, a banda de $100 \mathrm{kDa}$ não apresenta correspondência gênica com os genes cry já descritos, podendo ser uma nova toxina ainda não descrita. 
Figura 1 - Análise do perfil protéico das estirpes estudadas. M - marcador de massa molecular (Broad range - Promega, 1 - Btk, 2 - S2186 (4B), 3 - 2183 (6B).

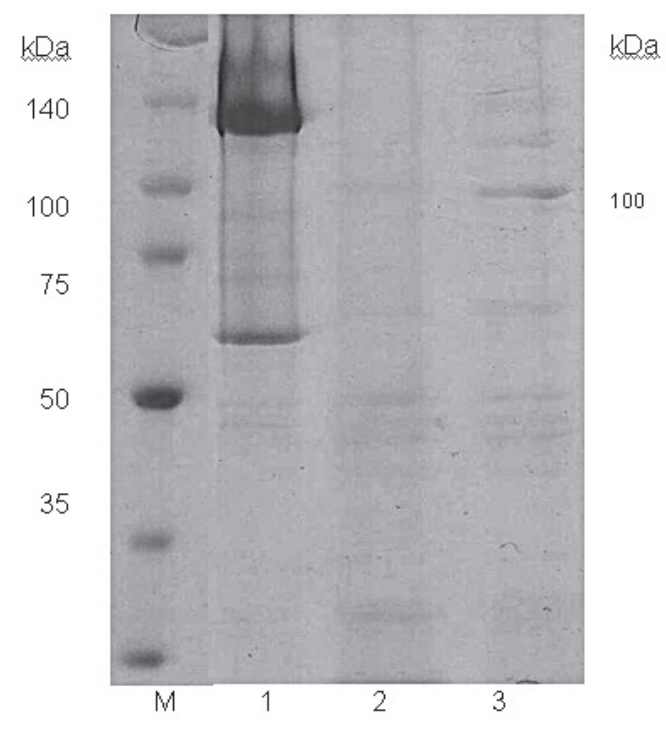

\subsection{Caracterização molecular}

A análise molecular revelou que tanto a estirpe S2183 como a S2186 não possuem genes cry1, pois não apresentaram fragmentos semelhantes aos desses genes (Figura 2). Porém, a estirpe S2186 apresentou um fragmento de PCR correspondente ao gene cry2, portanto a atividade entomopatogênica da estirpe S2186 a $P$. xylostella pode ter ocorrido em razão da presença desse gene, que codifica proteínas tóxicas a insetos da ordem Lepidoptera (MONNERAT et al., 1999; CÁRDENAS et al., 2001), sendo, também responsável pelo produto de expressão de 70 $\mathrm{kDa}$ mostrado na Figura 1. Com relação ao gene cry2 observado na estirpe S2186, são conhecidos cinco subgrupos dessa família, os genes cry2A, cry2Aa (DONOVAN et al. 1988), cry2Ab (Widner e Whiteley, 1989), cry2Ac (ZHANG et al. 2007), cry2Ad (GENEBANK: AF200816) e cry2Ae (GENEBANK: AAQ52362). As proteínas Cry2Aa e Cry2Ac apresentam atividade para insetos lepidópteros e dípteros, enquanto a Cry $2 \mathrm{Ab}$ é conhecida por ser tóxica somente para insetos lepidópteros (BRAVO, 2004; ZHANG et al. 2007). Portanto, pode ser que a atividade entomopatogência dessa estirpe a $P$. xylostella esteja ligada à proteína Cry2Aa. Maiores in- 
vestigações deverão ser feitas para confirmar esse resultado. Com relação à estirpe S2183, ela não apresentou nenhum produto de amplificação para os genes testados, o que leva a crer que ela pode possuir algum outro gene ainda não descrito, mas com baixa toxicidade a insetos lepidópteros.

Figura 2 - Análise do conteúdo gênico das estirpes estudadas por PCR. M - marcador de peso molecular (100 bp DNA Ladder - Amersham), (amostras de 1 a 4 - amplificação para o gene cry1): 1 - Controle negativo, 2 - Btk, 3 - S2183, 4 - S2186, (amostras de 5 a 8 amplificação para o gene cry2): 5 - Controle negativo, 6 - Btk, 7 - S2183 e 8 - S2186.

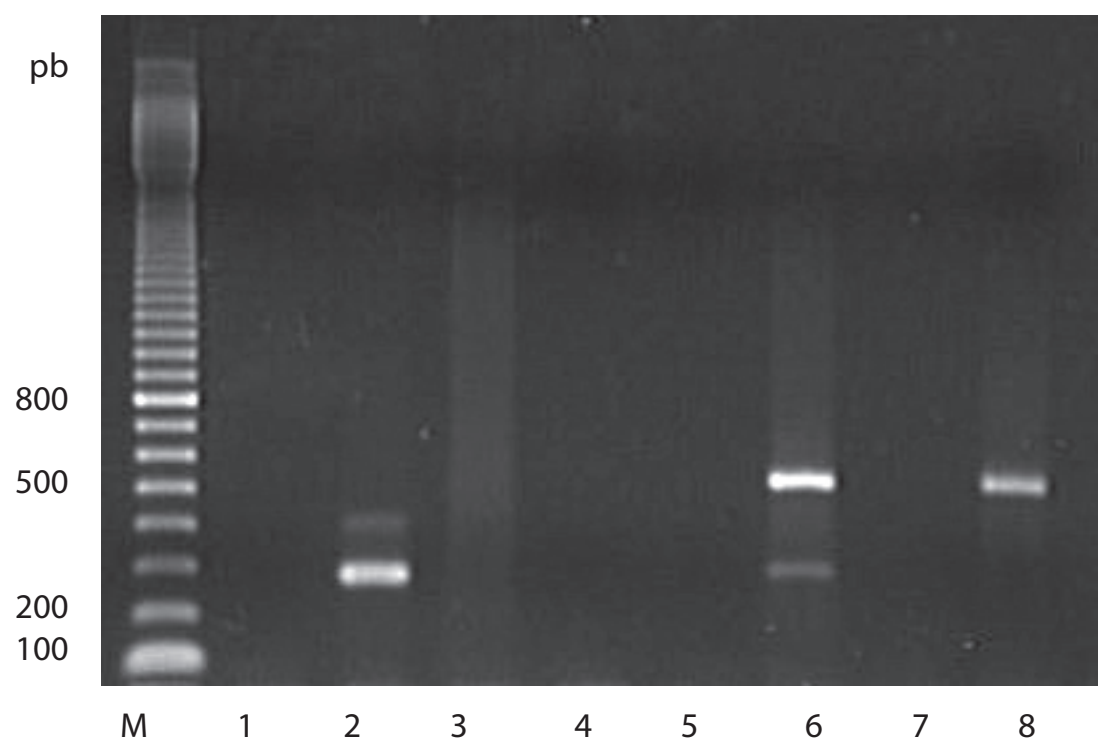

\subsection{Microscopia eletrônica dos isolados}

A análise morfológica, por meio de microscopia eletrônica de varredura, mostrou que a estirpe S2183 possui somente cristais redondos (Figura 3) e que a estirpe S2186 possui pequena quantidade de cristais bipiramidais e alguns cristais redondos bem pequenos (Figura 4). Essas formas podem fornecer indicações sobre a atividade de uma estirpe contra insetos da ordem Lepidoptera (HÖFTE et al., 1988). No entanto, o baixo percentual de cristais encontrados nessas estirpes, comparando aos já encontrados em outras estirpes estudadas (PRAÇA 
et al., 2004), pode justificar a baixa atividade apresentada por essas estirpes aos insetos da ordem Lepidoptera e não efetividade nas concentrações recomendadas.

Figura 3 - Esporos e cristais redondos da estirpe S2183

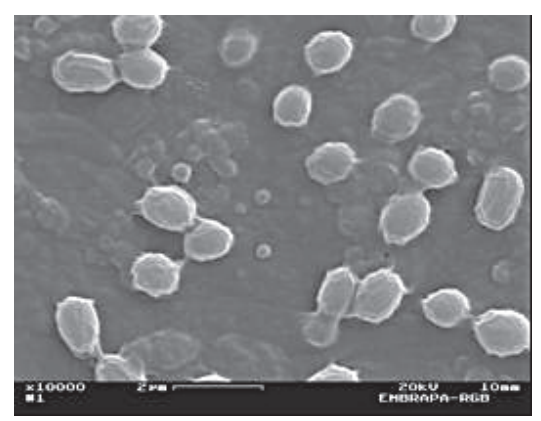

Figura 4 - Esporos e cristais bipiramidais da estirpe S2186

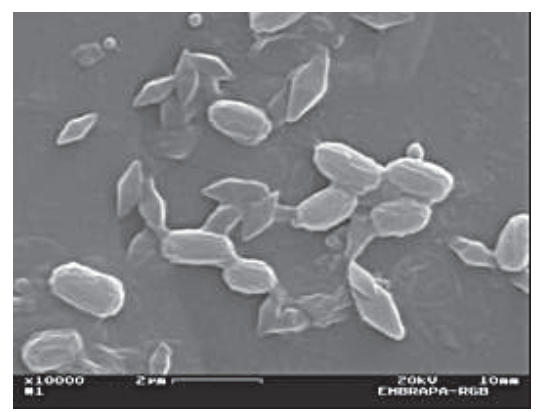

\section{Conclusão}

De todas as estirpes testadas, somente S2186 causou mortalidade acima de $75 \%$ em todos os insetos da ordem Lepidoptera testados (A. gemmetalis e S. frugiperda), e de $100 \%$ apenas em P. xylostella.

A estirpe S2183 causou mortalidade de 75\% a lagartas de S. frugiperda, mas não apresentou características estruturais e moleculares semelhantes à estirpe padrão Btk. 
Nenhuma estirpe apresentou atividade superior a 70\% a larvas de A. grandis.

As estirpes S2183 e S2186 apresentaram uma banda de $70 \mathrm{kDa}$ que se assemelha a uma das bandas presentes no perfil do padrão contra lepidópteros (Btk).

A estirpe S2186 apresentou um fragmento de PCR correspondente ao gene cry2, indicando ser esse o gene que codifica a proteína de $70 \mathrm{kDa}$, semelhante à estirpe padrão para o controle de lepidópteros, Btk.

\section{Isolation and characterization of Bacillus thuringiensis strains collected in soil of west Bahia.}

\section{Abstract}

By 21 soil samples of west Bahia region, nine Bacillus thuringiensis strains were isolated. The B. thuringiensis strains were tested against Spodoptera frugiperda, Anticarsia gemmatalis, Plutella xylostella and Anthonomus grandis. Two of nine strains of B. thuringiensis were efficient, S 2183 against S. frugiperda and S2186 against $S$. frugiperda, A. gemmatalis and P. xylostella. None of them caused more the $70 \%$ of death in A. grandis. These strains were submitted to a bioassay to calculate the LC50 and were characterized by biochemical and molecular methods. S2183 hadn't presented efficiency against the insects tested in the recommend concentrations and S2186 presented a LC50 of $375 \mu \mathrm{g} / \mathrm{mL}$ only against $P$. xylostella. The strains had presented two main proteins with 100 and $70 \mathrm{kDa}$ and only S2186 presented PCR products with expected size for detection of the genes cry2 and bipiramidal crystals that were similar to $B$. thuringiensis subspecies kurstaki standard.

Keywords: Spodoptera frugiperda. Insecticides. Biological Control. Insects.

\section{Referências}

BRAVO, A. et al. Characterization of cry genes in Mexican Bacillus Thuringiensis strain collection. Applied Environmental Microbiology, Washington, v. 64, n. 12, p. 4965-4972, 1998.

CÁRDENAS, M. I. et al. Selección de toxinas cry contra trichoplusia ni. Ciência Uanl, Valéncia, v. 6, n.1, p.51-62, Ene./Mar. 2001. 
CASTELO BRANCO, M. Avaliação da eficiência de formulações de Bacillus thuringiensis para o controle de traça-das-crucíferas em repolho no Distrito Federal. Horticultura Brasileira, Brasília, v. 17, n. 3, p. 237-240, 1999.

CERON, J. et al. PCR analysis of the cryi insecticidal crystal family genes from Bacillus thuringiensis. Applied environmental microbiology, Washingtorn, v. 60, n. 1, p. 353-356, 1994.

CERON, J. et al. Specific PCR primers directed to identify cryI and cryIII genes within a Bacillus thuringiensis strain collection. Applied environmental microbiology, Washington, v. 61, n. 11, p. 3826-3831, 1995.

CRUZ, I.; FIGUEIREDO, M. de L. C.; MATOSO, M. J. Controle biológico de spodoptera frugiperda utilizando o parasitóide de ovos trichogramma. Sete Lagoas: Embrapa Milho e Sorgo (Circular Técnica, 30), 1999.

DONOVAN, W. P. et al. Amino acid sequence and entomocidal activity of the p2 crystal protein. an insect toxin from Bacillus thuringiensis var. kurstaki. Journal of biological chemistry, Maryland, v. 263, n. 1, p. 561-56, 1988.

FINNEY, D. J. Probit analysis. England: Cambridge University Press, 1971.

GAZZONI, D. L.; YORINIORI, J. T. Manual de identificação de pragas e doenças da soja. Brasília: Embrapa, 1995.

GALLO, D. et al. Entomologia agrícola. Piracicaba: FEALQ, 2002.

GONDIM, D. M. C. et al. Manual de identificação das pragas, doenças, deficiências minerais e injúrias do algodoeiro no Brasil. 3. ed. Cascavel: COODETEC/CIRADCA, (Boletim Técnico n 33), 2001.

HÖFTE, H. et al. Monoclonal antibody analysis and insecticidal spectrum of three types of lepidopteran-specific insecticidal crystal proteins of Bacillus thuringiensis. Applied Environmental Microbiology, Washington, v. 54, n. 8, p. 2010-2017, 1988.

LAEMMLI, U. K. Cleavage of structural proteins during the assembly of the head of bacteriophage T4. Nature, London, v. 227, p. 680-685, 1970.

LECADET, M. M. et al. Construction of novel Bacillus thuringiensis strains with different insecticidal activities by transduction and transformation. Applied environmental microbiology, Washington, v. 58, n. 3, p. 840-849, 1991. 
LEE, M. K. et al. Synergistic effect of the Bacillus thuringiensis toxins CryIAa and CryIAc on the gypsy moth, Lymantria dispar. Applied environmental microbiology, Washington, v. 62, n. 2, p. 583-586, 1996.

LERECLUS, D.; DELÉCLUSE, A.; LECADET, M-M. Diversity of Bacillus thuringiensis Toxins and Genes. In: ENWISTLE, P. F. (Ed.). et al. Bacillus thuringiensis, an environmental biopesticide: theory and practice. Chichester: Wiley, 1993. p. 37-69.

MINISTÉRIO DA AGRICULTURA, PECUÁRIA E ABASTECIMENTO. Agronegócio brasileiro: uma oportunidade de investimentos. Disponível em: <http://www.agricultura.gov.br>. Acesso em: 28 fev. 2006.

MONNERAT, R. G. et al. Differential activity and activation of Bacillus thuringiensis insecticidal proteins in Diamondback moth, Plutella xylostella. Current Microbiology, New York, v. 39, n. 3, p. 159-162, 1999.

MONNERAT, R. G.; SILVA, S. F.; SIVA-WERNECK, J. O. Catálogo do banco de germoplasma de bactérias do gênero Bacillus. Brasília: Embrapa Recursos Genéticos e Biotecnologia, 2001.

MONNERAT, R. G. et al. Screening of Bacillus thuringiensis strains effective against mosquitoes. Pesquisa, Agropecuária Brasileira, Brasília, v. 40, n. 2, p. 103-106, 2005.

MONNERAT, R. G. et al. Characterization of brazilian Bacillus thuringiensis strains active against Spodoptera frugiperda, Plutella xylostella and Anticarsia gemmatalis. Biological control, [S.l], v. 41, n. 3, p. 291-295, 2007.

PRAÇA, L. B. Prospecção de estirpes brasileiras de Bacillus thuringiensis efetivas contra insetos da ordem Lepidoptera, Coleoptera e Diptera. 2003. 117 f. Dissertação (Mestrado), Universidade de Brasília, Brasília, 2003.

PRAÇA, L. B. et al. Estirpes de Bacillus thuringiensis efetivas contra insetos das ordens Lepidoptera, Coleoptera e Diptera. Pesquisa agropecuária brasileira, Brasília, v. 39, n.1, p. 11-16, 2004.

SANTOS, K. et al. Selection and characterization of the Bacillus thuringiensis strains toxic to Spodoptera eridania (Cramer), Spodoptera cosmioides (Walker) and Spodoptera frugiperda (Smith) (Lepidoptera:Noctuidae). Biological control, [S.1], v. 50, n. 2, p. 157-163, 2009. 
SILVA-WERNECK, J. O.; MONNERAT, R. Metodologias para caracterização de isolados de Bacillus thuringiensis. Brasília: Embrapa Recursos Genéticos e Biotecnologia (Circular Técnica, 10), 2001.

WIDNER W. R.; WHITELEY H. R. Two highly related insecticidal crystal proteins of Bacillus thuringiensis subsp kurstaki possess different host range specificities. Journal of bacteriology, Washington, v. 171, n. 2, p. 965-974, 1989.

ORGANIZAÇÃO MUNDIAL DA SAÚDE. Report of an informal consultation on the detection, isolation, identification and ecology of biocontrol agents of disease vectors. Genebra, 1987.

YOUSTEN, A. A. Bacillus sphaericus: microbiological factors related to its potencial as a mosquito larvicide. Advances in biotechnology processes, United States, v. 3, p. 315-343, 1984.

ZHANG L. L. et al. A novel Bacillus thuringiensis strain LLB6, isolated from bryophytes, and its new cry2Ac-type gene. Letters in Applied Microbiology, England, v. 44, n. 3, p. 301-307, 2007. 